\title{
Milk production potential of two ryegrass cultivars with different total non-structural carbohydrate contents
}

\author{
R. Meeske ${ }^{1 \#}$, P.R. Botha ${ }^{1}$, G.D. van der Merwe ${ }^{1}$, J.F. Greyling ${ }^{1}$, C. Hopkins ${ }^{2}$ and J.P. Marais ${ }^{2}$ \\ ${ }^{1}$ Department of Agriculture Western Cape, Outeniqua Research Farm, P.O. Box 249, George 6530, South Africa \\ ${ }^{2}$ KwaZulu-Natal Department of Agriculture and Environmental Affairs, Private Bag X9059, \\ Pietermaritzburg 3200, South Africa
}

\begin{abstract}
The aim of the study was to compare a new Italian ryegrass (Lolium multiflorum) cultivar (Enhancer), bred to contain a high total non-structural carbohydrate content, with the cultivar, Dargle, in terms of dry matter (DM) production, nutritional value, carrying capacity and milk production. The ryegrass cultivars were sown $(25 \mathrm{~kg} / \mathrm{ha})$ under supplementary irrigation in a randomized block design (7 blocks with 2 paddocks, 4.5 ha/treatment) on the $2^{\text {nd }}$ May 2001 (year 1) and the $15^{\text {th }}$ March 2002 (year 2) on an Estcourt soil type. Nitrogen was applied at $56 \mathrm{~kg}$ N/ha after each grazing. Grazing started on 26 June 2001 and the grazing cycle varied from 24 to 28 days. Pasture yield was estimated with a rising plate pasture meter. Forty Jersey cows from 50 to 150 days in milk were randomly allocated to one of the two treatments. The experimental period started on 22 August 2001 and consisted of an adaptation period of 15 days followed by a measurement period of 75 days. Pasture was allocated at $10 \mathrm{~kg} \mathrm{DM} /$ cow/day above $30 \mathrm{~mm}$. Cows were weighed and condition scored on two consecutive days at 14:00 at the start and the end of the experimental period. Milk production was recorded daily and milk composition was determined every 14 days. All cows were fed a flat rate of $3.6 \mathrm{~kg}$ DM of a dairy concentrate (120 g crude protein (CP) $/ \mathrm{kg}$ DM, $11.5 \mathrm{MJ} \mathrm{ME} / \mathrm{kg}$ $\mathrm{DM})$ per day. The concentrate was fed in two equal portions during milking at 06:00 and 15:00. The total production of Enhancer was higher at 8438 and $9084 \mathrm{~kg} \mathrm{DM} / \mathrm{ha}$ in 2001 and 2002, respectively, compared to 7570 and $7694 \mathrm{~kg} \mathrm{DM} /$ ha of Dargle. The DM and total non-structural carbohydrate content of Enhancer was higher than Dargle in 2001 but not in 2002. In 2002 the CP content of Enhancer was lower than that of Dargle. Enhancer increased 4\% fat corrected milk production by 1.3 and $1.4 \mathrm{~kg} / \mathrm{cow} /$ day in 2001 and 2002, respectively, and DM intake by 1.1 and $0.88 \mathrm{~kg} / \mathrm{cow} /$ day compared to Dargle. The total milk production per hectare of Enhancer was $1499 \mathrm{~kg}$ and $2277 \mathrm{~kg}$ higher during 2001 and 2002, respectively, compared to Dargle. Enhancer, a high sugar Italian ryegrass, demonstrated good potential to increase milk production.
\end{abstract}

Keywords: Carrying capacity, nutritional value, dry matter production, regression rising plate meter

\# Corresponding author. E-mail: Robinm@elsenburg.com

\section{Introduction}

The first limiting factor for milk production from pasture is the intake of metabolisable energy (ME) (Bargo, 2003; Kolver, 2003). It has been shown by Miller et al. (2001) that the selection of grasses for higher levels of total non-structural carbohydrates (TNC) might increase palatability, intake and milk production. The studies of Taweel et al. (2005) and Tas et al. (2005), however, did not confirm this. High quality ryegrass often has a low dry matter (DM) content which may restrict the intake of grass by dairy cows (Bargo et al., 2003). In South Africa the Lolium multiflorum (Italian ryegrass) cultivar, Enhancer (formerly referred to as Selection 121C), has been selected and bred for increased TNC and DM content. Marais et al. (2003) showed that the DM production of Enhancer compared well with that of other cultivars. Enhancer had a higher DM content and more favourable nitrogen to energy ratio than other cultivars. The mean DM content of Enhancer was 20.8\%, which was higher than other ryegrass cultivars (Marais \& Goodenough, 2000). The mean TNC content of Enhancer was $286 \mathrm{~g}$ TNC/kg DM which was 43\% higher than that of other cultivars (Marais \& Goodenough, 2000). This may result in a more rapid rate of digestion and a higher digestibility of the grass. Dargle has been chosen to compare with Enhancer because it has a similar Westerwold and Italian component and a similar growth curve as Enhancer (Marais \& Goodenough, 2000). The aim of the study was to compare a new Italian ryegrass cultivar, Enhancer, bred to yield a higher DM and non-structural carbohydrate content than an existing cultivar, Dargle, in terms of DM yield, chemical 
composition, intake, carrying capacity and milk production of Jersey cows.

\section{Materials and Methods}

Nine hectares of an Estcourt soil type (Soil Classification Working Group, 1991) under permanent irrigation at the Outeniqua Research Farm near George (Altitude $201 \mathrm{~m}, 33^{\circ} 58^{\prime} 38^{\prime \prime S}$ and $22^{\circ} 25^{\prime} 16^{\prime \prime} \mathrm{E}$ ) in the Western Cape of South Africa were used in the study. The nine hectares were divided into 14 experimental paddocks of $6429 \mathrm{~m}^{2}$ which were grouped into seven blocks. The Italian ryegrass cultivars, Enhancer and Dargle, were randomly allocated to one of the two experimental paddocks in each block. Forty multiparous Jersey cows were divided into pairs with similar milk production, lactation number and days in milk. Within each pair the cows were randomly allocated to one of the two pasture treatments. The cows strip-grazed four days on each paddock, resulting in a 28-day grazing cycle.

The area had previously been under a perennial ryegrass/clover pasture. In November 2000 Eragrostis teff was planted on the area and it was grazed three times by lactating dairy cattle. During the last week of March 2001 the area was sprayed with a herbicide (Glyphosate at 3 litres/ha), excess material was removed with a Taarup silage chopper, fertilizer was applied and the soil was worked with a heavy disc. Fertilizer was applied to raise soil P levels to $35 \mathrm{mg} / \mathrm{kg}$, K levels to $80 \mathrm{mg} / \mathrm{kg}$ and the soil $\mathrm{pH}$ (KCl) to 5.5 (Beyers, 1983). To prepare the seedbed three weeks later the soil was worked with a heavy disc followed by a Kongskilde and Cambridge roller. Seed of the ryegrass cultivars, Dargle and Enhancer, were broadcast by hand at a rate of $31 \mathrm{~kg} / \mathrm{ha}$ on the $2^{\text {nd }}$ of May 2001 and the seedbed was rolled again. The germination rate of seed was $80 \%$ resulting in an effective $25 \mathrm{~kg}$ of ryegrass seed per hectare. The pastures were irrigated according to tensiometer readings, and tensiometer readings were kept between -10 and $-25 \mathrm{kPa}$ (Botha, 2003). When the pasture reached a height of $100 \mathrm{~mm}, 28 \mathrm{~kg} \mathrm{~N} / \mathrm{ha}$ as limestone ammonium nitrate (LAN) was applied. Nitrogen (LAN) was applied at $56 \mathrm{~kg} \mathrm{~N} / \mathrm{ha}$ after each grazing. In year 1, grazing started on the $26^{\text {th }}$ of June 2001 and lasted until the $7^{\text {th }}$ of December 2001. During 2002 the same procedure was followed to plant the ryegrasses but the grasses were sown earlier on the $11^{\text {th }}$ of March 2002 and grazing started on the $11^{\text {th }}$ of May 2002. The pasture was grazed until the $9^{\text {th }}$ of December 2002.

In 2001 the milk production study started on 22 August, and consisted of an adaptation period of 15 days followed by a measuring period of 75 days. At the start of the study in 2001 the average milk production of the cows four weeks prior to the start of the study, days in milk and lactation number were $18.3 \pm 2.38$ and $18.3 \pm 2.30 \mathrm{~kg} ; 94 \pm 47$ and $93 \pm 48$ days, and $2.9 \pm 1.59$ and $3.3 \pm 2.09$ lactations for the cows on Dargle and Enhancer, respectively. During 2002 the milk production study started on the $3^{\text {rd }}$ of September, and consisted of an adaptation period of 15 days followed by a measurement period of 82 days. The average milk production of cows four weeks prior to the start of this study, days in milk and lactation number were $17.8 \pm 1.82$ and $17.7 \pm 4.15 \mathrm{~kg} ; 124 \pm 36$ and $125 \pm 39$ days, and $2.8 \pm 1.60$ and $2.8 \pm 1.86$ lactations for cows grazing the Dargle and Enhancer, respectively.

The cows were weighed and condition scored (Mulvany, 1977) on two consecutive days at 14:00, at the start and end of the experimental periods. Milk production was recorded daily and milk composition was determined every 14 days on a composite morning and afternoon milk sample. The protein, butterfat and milk urea nitrogen content of the milk was determined according to the International IDF standard 141B (IDF, 1996) with a Milkoscan FT 6000 analyzer (Foss Electric, Denmark). All cows were fed a flat rate of $3.6 \mathrm{~kg} \mathrm{DM} /$ day of a maize-soya based dairy concentrate (120 g CP/kg DM; $11.5 \mathrm{MJ} \mathrm{ME} / \mathrm{kg} \mathrm{DM})$. The concentrate was fed during milking at 06:00 and 15:00 in equal portions. Representative samples of the concentrate were taken weekly during the measurement period for analysis.

Pasture yields were estimated using a rising plate pasture meter (RPM) (Fulkerson, 1997). Linear regressions to calculate the DM yield were obtained by selecting three high, medium and low grass heights in block 1, 3 and 5 for each grass during each grazing cycle just before grazing. Grass beneath the rising plate was cut at a height of $30 \mathrm{~mm}$ and dried in an oven at $60^{\circ} \mathrm{C}$ for $72 \mathrm{~h}$. Regressions were calculated using yield as the dependent variable and height as the independent variable. Pasture yield was estimated by taking 100 RPM readings before and after grazing on each strip during the total growth period of the two cultivars. Each paddock was grazed in two strips (two days per strip, i.e. four grazings) with each strip divided into four areas of $878 \mathrm{~m}^{2}$ for each grazing by making use of an electric fence. The number of cows was adjusted in a put and take system depending on the amount of DM available and $10 \mathrm{~kg}$ of DM above $30 \mathrm{~mm}$ was allocated per cow per day. At least 20 cows were kept on each treatment during the milk production study. 
(C) South African Society for Animal Science

Four random samples from each pasture treatment were cut $30 \mathrm{~mm}$ above ground level on blocks 1,3 and 5 prior to grazing. The four samples were pooled for each block. The pooled samples were dried and milled through a $1 \mathrm{~mm}$ sieve.

The DM, TNC, in vitro organic matter digestibility (IVOMD), crude protein (CP), true protein, nitrate$\mathrm{N}$, neutral detergent fibre (NDF), acid detergent fibre (ADF), Ca and $\mathrm{P}$ of pasture and concentrate samples were determined. Dry matter was determined by drying samples for $72 \mathrm{~h}$ in a forced draught oven at $60{ }^{\circ} \mathrm{C}$. Total non-structural carbohydrates were analyzed as reducing sugars following quantitative hydrolysis to monosaccharides through a carefully controlled acid hydrolysis procedure (Marais, 1979). The reducing sugars formed during hydrolysis were determined quantitatively by a modified Nelson-Somogyi method (Marais et al., 1966). Grass samples were initially digested under conditions simulating rumen fermentation, which was followed by an acid pepsin digestion to solubilise the protein in the sample. True protein determinations were performed using the procedure described by Marais \& Evenwell (1983). The method was based on the precipitation of protein with trichloroacetic acid (TCA) and the separation of the insoluble protein from the soluble non-protein fraction by means of filtration. Nitrogen in the fractions was determined by means of an auto analyser. The nitrate-N procedure was based on the nitration of salicylic acid under highly acidic conditions and the colorimetic determination of the resulting coloured complex which absorbs maximally at $410 \mathrm{~nm}$ in the basic solution (Cataldo et al., 1975). The NDF, ADF and ADL concentrations were determined according to Van Soest et al. (1991). Mineral analyses of samples were conducted using the 'Hunter' system, as described by Farina (1981). After dry ashing, P was determined colorimetrically and cations (Ca, Mg, K, Al, Zn and Mn) by atomic absorption spectrophotometry.

Statistical analysis was done using the paired t-test (McCall, 1970). A two-tailed test was performed on data. The seven pasture blocks with one paddock for each grass were regarded replicates over time (Wilkins et al., 1995). Cows were regarded as the replicates in the analysis of lactation data. When the observed t-value was greater than 2.093, the hypothesis that the means for treatments were similar was rejected, and a significant $(\mathrm{P}<0.05)$ difference was declared.

\section{Results and Discussion}

The total annual rainfall and average minimum temperature were 807 and $577 \mathrm{~mm}$, and 11.8 and $11.1^{\circ} \mathrm{C}$ during 2001 and 2002, respectively. The average maximum temperature for both years was $21.8^{\circ} \mathrm{C}$. Dry matter production and growth rate of ryegrass during 2001 and 2002 are given in Table 1. In both years total DM production of Enhancer was higher $(\mathrm{P}<0.01)$ than that of Dargle. The highest growth rate was obtained during October and November 2001 and November and December 2002. The regressions for the rising plate meter $(\mathrm{RPM})(\mathrm{n}=162$ in 2001, $\mathrm{n}=189$ in 2002) used to calculate the DM yield per hectare and to allocate cows to the pasture were:

$\begin{array}{lll}\text { Dargle (2001) } & \text { : Yield }(\mathrm{kg} \mathrm{DM} / \mathrm{ha})=(61.61 \text { X RPM Height })-265 & \mathrm{R}^{2}=0.76 \\ \text { Enhancer (2001) } & \text { : Yield (kg DM/ha) }=(70.09 \text { X RPM Height })-434 & \mathrm{R}^{2}=0.77 \\ \text { Dargle (2002) } & \text { : Yield (kg DM/ha) }=(55.62 \text { X RPM Height })-154 & \mathrm{R}^{2}=0.70 \\ \text { Enhancer (2002) } & \text { : Yield (kg DM/ha) }=(\text { (64.48 X RPM Height) }-326 & \mathrm{R}^{2}=0.81\end{array}$

The chemical composition of ryegrass during 2001 and 2002 is given in Tables 2 and 3, respectively. During 2001 the DM content and TNC content of Enhancer were higher $(\mathrm{P}<0.05)$ than that of Dargle while the CP, $\mathrm{ADL}, \mathrm{K}, \mathrm{Zn}$ and $\mathrm{Cu}$ levels were lower $(\mathrm{P}<0.05)$. This is in agreement with Hopkins et al. (2002) who compared Enhancer (formerly known as Italian ryegrass selection 121) with Midmar and also reported a higher DM and TNC content and a lower mineral concentration. The TNC content for Enhancer shown in Table 3 is comparable to the $64.9 \mathrm{~g}$ TNC/kg DM reported by Hopkins et al. (2002) in growth chambers with a warm climate regimen (day/night temperature of $30^{\circ} \mathrm{C} / 20^{\circ} \mathrm{C}$ ). Total non-structural carbohydrate content of Enhancer was higher (150 g TNC/kg DM) under lower temperatures (day/night temperature of $20{ }^{\circ} \mathrm{C} / 7$ ${ }^{\circ} \mathrm{C}$ ). During 2002 the TNC content of Enhancer was $101 \mathrm{~g}$ TNC/kg DM. Parsons et al. (2004) reported that the water soluble carbohydrate (WSC) content of a perennial ryegrass varied from 60 to $180 \mathrm{~g} / \mathrm{kg}$ DM. Grasses sustained higher levels of WSC in cold than in hot climates. It is to be expected that the fibre content of grasses bred to contain a higher TNC content will be lower. The NDF and ADF levels of Enhancer were lower $(\mathrm{P}<0.05)$ than that of Dargle in the second year of the study but not in the first. The ADL content of 
grasses did not differ in the second year but the ADL of Enhancer was lower $(\mathrm{P}=0.04)$ than that of Dargle in the first year. The nitrate- $\mathrm{N}$ content of Enhancer was lower $(\mathrm{P}<0.001)$ than that of Dargle in Table 3 as was also found by Hopkins et al. (2002). The mineral content of high sugar grasses may be lower than that of other grasses.

In 2001 the $\mathrm{K}, \mathrm{Zn}$ and $\mathrm{Cu}$ concentrations of Enhancer were lower $(\mathrm{P}<0.05)$ than in Dargle. In 2002 the $\mathrm{Mg}$ and Zn concentrations of Enhancer were lower $(\mathrm{P}<0.05)$ than that of Dargle. Hopkins et al. (2002) found lower levels of $\mathrm{Mg}, \mathrm{K}, \mathrm{Na}$ and $\mathrm{Mn}$ in Enhancer compared to cultivar, Midmar. The milk production,

Table 1 Total dry matter (DM) production and growth rate of Italian rygrasses Dargle and Enhancer during 2001 and $2002(n=7)$

\begin{tabular}{lcccc}
\hline & Dargle & Enhancer & s.e.m. & P-value \\
\hline $\begin{array}{l}\text { Total DM production in 2001 (kg/ha) } \\
\text { DM production (kg/ha/day) }\end{array}$ & 7570 & 8438 & 186 & $<0.01$ \\
$\quad$ June & 25.9 & 25.4 & 2.00 & 0.92 \\
July & 27.9 & 28.6 & 1.81 & 0.72 \\
August & 38.3 & 40.6 & 2.90 & 0.44 \\
September & 49.3 & 55.2 & 2.72 & 0.05 \\
October & 51.8 & 58.3 & 3.54 & 0.08 \\
November & 59.9 & 63.9 & 2.85 & 0.17 \\
& & & & \\
Total DM production in 2002 (kg/ha) & 7694 & 9084 & 186 & $<0.01$ \\
DM production (kg/ha/day) & & & \\
May & 26.8 & 28.2 & 2.14 & 0.68 \\
$\quad$ June & 22.8 & 23.7 & 1.15 & 0.69 \\
July & 24.5 & 25.7 & 2.00 & 0.67 \\
August & 35.2 & 46.2 & 4.74 & 0.26 \\
September & 38.8 & 40.3 & 2.26 & 0.67 \\
October & 39.7 & 47.3 & 3.53 & 0.48 \\
November & 46.9 & 58.9 & 9.54 & 0.24 \\
December & 49.4 & 63.3 & 6.13 & 0.12 \\
\hline
\end{tabular}

Table 2 The mean chemical composition of Italian ryegrasses Dargle and Enhancer from June to November $2001(n=18)$

\begin{tabular}{lcccc}
\hline Chemical composition $^{\text {a }}$ & Dargle & Enhancer & s.e.m. $^{\text {b }}$ & P-value \\
\hline Dry matter (DM, g/kg fresh weight) & 113 & 131 & 1.7 & $<0.001$ \\
Crude protein & 228 & 211 & 4.8 & 0.07 \\
Nitrate-N & 19.4 & 15.0 & 4.10 & 0.26 \\
Total non-structural carbohydrates (TNC) & 52 & 76 & 9.7 & 0.03 \\
Neutral-detergent fibre (NDF) & 477 & 471 & 6.1 & 0.31 \\
Acid-detergent fibre (ADF) & 323 & 314 & 7.6 & 0.08 \\
Acid-detergent lignin (ADL) & 83 & 75 & 3.9 & 0.04 \\
Calcium & 5.5 & 5.5 & 1.65 & 0.95 \\
Phosphorous & 4.5 & 4.5 & 0.24 & 0.79 \\
Magnesium & 3.3 & 3.2 & 0.15 & 0.55 \\
Sodium & 11.5 & 8.9 & 1.46 & 0.29 \\
Potassium & 44 & 37 & 2.3 & 0.03 \\
Zinc (mg/kg DM) & 45 & 38 & 2.2 & 0.01 \\
Copper (mg/kg DM) & 8.3 & 6.6 & 0.60 & 0.01 \\
Manganese (mg/kg DM) & 43 & 46 & 4.2 & 0.46 \\
\hline Giva (on & & & & \\
\hline
\end{tabular}

${ }^{\mathrm{a}}$ Given as concentration (g/kg DM) unless stated otherwise; ${ }^{\mathrm{b}}$ s.e.m. - standard error of mean. 
Table 3 The mean chemical composition of Italian ryegrasses Dargle and Enhancer from May to December $2002(n=23)$

\begin{tabular}{lcccc}
\hline Nutrient composition $^{\mathrm{a}}$ & Dargle & Enhancer & s.e.m. $^{\text {b }}$ & P-value \\
\hline Dry matter (DM, g/kg fresh weight) & 129 & 136 & 6.9 & 0.57 \\
Crude protein & 243 & 217 & 8.5 & 0.004 \\
Nitrate-N & 14.7 & 8.3 & 0.95 & $<0.001$ \\
Total non-structural carbohydrates (TNC) & 87 & 101 & 13.4 & 0.20 \\
Neutral-detergent fibre (NDF) & 605 & 586 & 8.4 & 0.04 \\
Acid-detergent fibre (ADF) & 357 & 326 & 4.9 & $<0.001$ \\
Acid-detergent lignin (ADL) & 82 & 86 & 3.0 & 0.11 \\
Calcium & 5.2 & 5.0 & 0.18 & 0.34 \\
Phosphorus & 4.0 & 3.9 & 0.28 & 0.86 \\
Magnesium & 3.2 & 3.0 & 0.13 & 0.03 \\
Sodium & 13.0 & 10.4 & 1.71 & 0.41 \\
Potassium & 34 & 34 & 3.1 & 0.91 \\
Zinc (mg/kg DM) & 58 & 47 & 3.6 & 0.03 \\
Copper (mg/kg DM) & 7.1 & 7.2 & 0.61 & 0.31 \\
Manganese (mg/kg DM) & 55 & 56 & 5.4 & 0.46 \\
\hline
\end{tabular}

${ }^{a}$ Given as concentration (g/kg DM) unless stated otherwise; ${ }^{b}$ s.e.m. - standard error of mean.

Table 4 Milk production, milk composition, intake, live weight change and condition score change of Jersey cows $(n=20)$ grazing on Italian ryegrass cultivars, Dargle or Enhancer, from September to November 2001 (cows were fed $3.6 \mathrm{~kg}$ DM of concentrate per day)

\begin{tabular}{lcccc}
\hline & Dargle & Enhancer & s.e.m. & P-value \\
\hline Milk production (kg/day) & 17.8 & 18.7 & 0.35 & 0.002 \\
Fat corrected milk 4\% (kg/day) & 17.8 & 19.1 & 0.42 & 0.01 \\
Milk fat \% & 4.00 & 4.10 & 0.086 & 0.28 \\
Milk protein \% & 3.43 & 3.48 & 0.025 & 0.11 \\
Milk urea nitrogen (mg/dL) & 13.9 & 12.7 & 0.28 & 0.03 \\
Pasture dry matter intake (kg/day) & 7.6 & 8.7 & 0.25 & $<0.01$ \\
Live weight change (kg)/75 days & 19.8 & 27.0 & 2.35 & 0.04 \\
Condition score change (1-5)/75 days & 0.05 & 0.11 & 0.04 & 0.14 \\
Pasture measurements before grazing & & & & \\
$\quad$ Rising plate meter height & 26.3 & 26.7 & 0.49 & 0.75 \\
$\quad$ Yield (kg/ha) & 1358 & 1439 & 31.8 & 0.31 \\
Pasture measurements after grazing & & & & 0.26 \\
$\quad$ Rising plate meter height & 9.1 & 9.5 & 0.20 & 0.04 \\
$\quad$ Yield (kg/ha) & 292 & 233 & & \\
\end{tabular}

milk composition, DM intake, live weight change, condition score change of cows and pasture measurements before and after grazing, for Dargle and Enhancer are shown in Tables 5 and 6 for 2001 and 2002, respectively.

The FCM production of cows on Enhancer was $1.3 \mathrm{~kg} / \mathrm{cow} /$ day and $1.4 \mathrm{~kg} / \mathrm{cow} /$ day higher $(\mathrm{P}=0.01)$ than that of cows grazing on Dargle during 2001 and 2002, respectively. At a milk price of R3.00/kg, the monthly profit per cow on Enhancer would be between R 117 and R 126 higher compared to Dargle when stocking rates are similar. Miller et al. (2001) reported higher milk production without an increased DM intake on a perennial ryegrass with a high WSC content. Taweel et al. (2005) did not find an increased milk production or higher DM intake when cows were fed perennial ryegrass with a higher WSC content. In their study the grass was cut and fed to the cows. In our study cows grazed the grass over a long period (90 to 97 days) of time. The milk fat content of cows on Enhancer was higher $(P=0.02)$ than that of cows on Dargle 
Table 5 Milk production, milk composition, intake, live weight change and condition score change of Jersey cows $(n=20)$ grazing on Italian ryegrass cultivars, Dargle or Enhancer, from September to November 2002 (cows were fed $3.6 \mathrm{~kg}$ DM of concentrate per day)

\begin{tabular}{lcccc}
\hline & Dargle & Enhancer & s.e.m. & P-value \\
\hline Milk production (kg/day) & 17.2 & 17.6 & 0.23 & 0.03 \\
Fat corrected milk 4\% (kg/day) & 18.3 & 19.7 & 0.43 & 0.01 \\
Milk fat \% & 4.45 & 4.77 & 0.157 & 0.02 \\
Milk protein \% & 3.50 & 3.56 & 0.058 & 0.17 \\
Pasture dry matter intake (kg/day) & 7.17 & 8.05 & 0.296 & $<0.01$ \\
Live weight change (kg)/ 82 days & 54.1 & 48.0 & 3.59 & 0.06 \\
$\quad \begin{array}{l}\text { Condition score change (1-5)/ 82 days } \\
\text { Pasture measurements before grazing }\end{array}$ & 0.35 & 0.33 & 0.138 & 0.42 \\
$\quad$ Rising plate meter height & 27.7 & 28.7 & 0.60 & 0.49 \\
$\quad$ Yield (kg/ha) & 1389 & 1526 & 39.4 & 0.12 \\
Pasture measurements after grazing & & & & \\
$\quad$ Rising plate meter height & 9.5 & 10.3 & 0.27 & 0.14 \\
$\quad$ Yield (kg/ha) & 373 & 339 & 17.3 & 0.31 \\
\hline
\end{tabular}

during 2002, but this was not found in $2001(\mathrm{P}=0.28)$. No differences in milk protein content were found in 2001 and 2002. Although the MUN content of milk in 2001 was lower $(P=0.03)$ for cows on Enhancer than for cows on Dargle, this difference was biologically insignificant. Miller et al. (2001) also found no differences in milk composition when cows were fed ryegrass with a high WSC content. Dry matter intake of Enhancer was 14.5\% and 12.3\% higher $(\mathrm{P}<0.01)$ than that of Dargle in 2001 and 2002, respectively. The higher DM and TNC content my have resulted in the increased intake of Enhancer compared to Dargle. In the study of Miller et al. (2001) the DM intake was not higher when cows were fed ryegrass with a high WSC content but the intake of digestible DM was higher. The cows on Enhancer gained more weight $(\mathrm{P}<0.05)$ than cows on Dargle in 2001 but the live weight gain of cows did not differ $(\mathrm{P}>0.05)$ between treatments in 2002.

The Enhancer and Dargle carried $3.6 \pm 0.15$ and $3.0 \pm 0.4 ; 4.0 \pm 0.34$ and $3.5 \pm 0.78 ; 5.0 \pm 0.7$ and 4.5 \pm 0.3; $7.1 \pm 1.6$ and $7.0 \pm 1.9 ; 7.2 \pm 1.2$ and $7.1 \pm 1.2$; $6.6 \pm 0.6$ and $6.7 \pm 1.1$ cows/ha during June, July, August, September, October and November 2001, respectively. The calculated total $4 \%$ fat corrected milk production per hectare produced from 22 August to 5 December 2001 was $11860 \mathrm{~kg}$ for Enhancer and 11234 $\mathrm{kg}$ for Dargle (105 day period). No differences in carrying capacity were found between cultivars. During 2002 Enhancer and Dargle carried $3.2 \pm 0.98$ and $3.6 \pm 0.79$ cows/ha in May; $3.4 \pm 0.59$ and $3.6 \pm 0.77$ cows/ha in June; $3.9 \pm 1.10$ and $4.2 \pm 0.84$ cows/ha in July; $5.6 \pm 2.56$ and $4.3 \pm 1.42$ cows/ha in August; 5.3 \pm 0.84 and $5.0 \pm 0.79$ cows/ha in September; $7.7 \pm 2.38$ and $6.6 \pm 2.84$ cows/ha in October; $8.2 \pm 2.82$ and $6.3 \pm 1.72 \mathrm{cows} / \mathrm{ha}$ in November and $9.2 \pm 1.76$ and $7.6 \pm 1.3 \mathrm{cows} / \mathrm{ha}$ in December, respectively. The calculated total milk production per hectare produced from the $2^{\text {nd }}$ of September to the $6^{\text {th }}$ of December 2002 was $12552 \mathrm{~kg}$ for Enhancer and 10547 for Dargle (95 day period).

Pasture was grazed when there was between $1300 \mathrm{~kg}$ and $1500 \mathrm{~kg}$ DM available per hectare above 30 $\mathrm{mm}$. After grazing between $292 \mathrm{~kg}$ and $339 \mathrm{~kg}$ DM was left above a height of $30 \mathrm{~mm}$. The disk meter measurements after grazing indicate that was pasture well utilized $(78.4 \%$ of pasture above $30 \mathrm{~mm}$ height was grazed) with similar intensity on both grasses. Residual pasture was still available after grazing.

\section{Conclusions}

Enhancer increased 4\% fat corrected milk production of Jersey cows by $1.3 \mathrm{~kg} / \mathrm{day}$ and $1.4 \mathrm{~kg} / \mathrm{day}$ and DM intake by $1.1 \mathrm{~kg} /$ day and $0.88 \mathrm{~kg} /$ day compared to Dargle during 2001 and 2002, respectively. The total calculated milk production per hectare during the milk production study from Enhancer was increased by $626 \mathrm{~kg} / \mathrm{ha}$ and $2005 \mathrm{~kg} / \mathrm{ha}$ for 2001 and 2002, respectively compared to that from Dargle. The DM and TNC content of Enhancer were higher than that of Dargle during 2001. Enhancer, a high sugar Italian ryegrass has the potential to increase milk production per cow. 


\section{References}

Bargo, F., Muller, L.D., Kolver, E.S. \& Delahoy, J.E., 2003. Invited Review: Production and digestion of supplemented dairy cows on pasture. J. Dairy Sci. 86, 1-42.

Beyers, C.P.de L., 1983. Bemesting van aangeplante weidings. Winterreën, Spes. uitgawe, no. 5, 54-59.

Botha, P.R., 2003. The production potential of over-sown kikuyu pasture in the temperate coastal area of the Southern Cape. PhD thesis, University of the Free State, South Africa.

Cataldo, D.A., Haroon, M., Schrader, L.E. \& Young, V.L., 1975. Rapid colorimetric determination of nitrate in plant tissue by nitration of salicylic acid. Communication of the Soil Science and Plant Analist. 6, 71-80.

Farina, M.P.W., 1981. The Hunter system of soil analysis. J. Fertil. Soc. S. Afr. 1, 39-41.

Fulkerson, W.J., 1997. Use of the rising plate meter to allocate pasture. Research to Farm. NSW Agriculture. Wollungbar Agriculture Institute, May 1997, Australia.

Hopkins, C., Marais, J.P. \& Goodenough, D.C.W., 2002. A comparison, under controlled environmental conditions, of a Lolium multiflorum selection bred for high dry matter content and non-structural carbohydrate concentration with a commercial cultivar. Grass For. Sci. 57, 367-372.

IDF, 1996. International Dairy Federation, Standard 141B, IDF General Secretariat, Diamant Building, Boulevard Auguste Reyers 80, 1030, Brussels, Belgium. E-mail: info@fil-idf.org.

Kolver, E.S., 2003. Nutritional limitations to increased production on pasture-based systems. Proc. Nutr. Soc. 62, 291-300.

Marais, J.P., 1979. Evaluation of acid hydrolysis procedures for the rapid determination of total nonstructural carbohydrates in plant species. Agrochemophys. 11, 1-3.

Marais, J.P. \& Evenwell, T.K., 1983. The use of trichloro-acetic acid as precipitant for the determination of ‘true protein' in animal feeds. S. Afr. J. Anim. Sci. 13, 138 - 139.

Marais, J.P. \& Goodenough, D.C.W., 2000. Nutritive value and dry matter yield of annual ryegrass Enhancer, as compared to other cultivars developed at Cedara. Proc. S.A. Soc. Anim. Sci., Congress, 38 from 25 to 27 July 2000, Alpine Heath Conference Village, KwaZulu-Natal. pp. 161-162.

Marais, J.P., De Wit, J.L. \& Quicke, G.V., 1966. A critical evaluation of the Nelson-Somogyi method for the determination of reducing sugars. Anal. Biochem. 15, 373-381.

Marais, J.P., Goodenough, D.C.W., de Figueiredo, M. \& Hopkins, C., 2003. The development of a Lolium multiflorum cultivar with a low moisture content and an increased readily digestible energy to protein ratio. Aust. J. Agric. Res. 54, 101-106.

McCall, R.B., 1970. Fundamental Statistics for Psychology. Harcourt, Brace \& World, Inc., New York. pp. 177-190.

Miller, L.A., Moorby, J.M., Davies, D.R., Humphreys, M.O., Scollan, N.D., MacRae, J.C. \& Theodorou, M.K., 2001. Increased concentration of water-soluble carbohydrate in perennial ryegrass (Lolium perenne L.): Milk production from late-lactation dairy cows. Grass For. Sci. 56, 383-394.

Mulvany, P., 1977. Dairy cow condition scoring (Leaflet no 4468). National Institute for Research in Dairying, Shinfield, RG2 (AT, UK).

Parsons, A.J., Rasmussen, S., Xue, H., Newman, J.A., Anderson, C.B. \& Cosgrove, G.P., 2004. Some high sugar grasses don’t like it hot. Proc. N. Z. Grassl. Assoc. 66, 265-271.

Soil Classification Working Group, 1991. Soil classification. A Taxonomic System for South Africa. Memoirs of Natural Agricultural Resources of South Africa, No 15. Department of Agricultural Development, Pretoria.

Tas, B.M., Taweel, H.Z., Smit, J.H., Elgersma, A., Dijkstra, J. \& Tamminga, S., 2005. Effects of perennial ryegrass cultivars on intake, digestibility and milk yield. J. Dairy Sci. 88, 3240-3248.

Taweel, H.Z., Tas, B.M., Smit, H.J., Elgersma, A., Dijkstra, J. \& Tamminga, S., 2005. Effects of feeding perennial ryegrass with an elevated concentration of water-soluble carbohydrates on intake, rumen function and performance of dairy cows. Anim. Feed Sci. Technol. 121, 243-256.

Van Soest, P.J., Robertson J.B. \& Lewis, B.A., 1991. Symposium: Carbohydrate methodology, metabolism, and nutritional implications in dairy cattle. J. Dairy Sci. 74, 3583-3597.

Wilkins, R.J., Gibb, M.J. \& Huckle, C.A., 1995. Lactation performance of spring-calving dairy cows grazing mixed perennial ryegrass/white clover swards of differing composition and height. Grass For. Sci. 50, 199-208. 